Journal of Economic, Business and Accounting (COSTING)

Volume 1, Nomor 2, Juni 2018

e-ISSN : 2597-5234

https://doi.org/10.31539/costing.v1i2.207

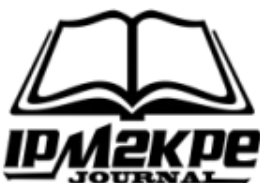

\title{
PENGARUH KUALITAS PELAYANAN, KEPUASAN DAN INSENTIF TERHADAP PERILAKU WORD OF MOUTH (WOM) MAHASISWA STIE PELITA INDONESIA
}

\section{THE EFFECT OF SERVICE QUALITY, SATISFACTION AND INCENTIVES TOWARD WORD OF MOUTH BEHAVIOR ON STIE PELITA INDONESIA PEKANBARU STUDENTS}

\author{
Astri Ayu Purwati, Onny Setiawan \\ Program Studi Manajemen Sekolah Tinggi Ilmu Ekonomi Pelita Indonesia \\ astriayu90@gmail.com
}

\begin{abstract}
Increasing number of universities in Indonesia today demanding all universities both public and private to be able to improve the quality of competition. One of them is through the right marketing strategy. This study aims to determine the effect of service quality, satisfaction and incentives towardn word of mouth behavior on STIE Pelita Indonesia Pekanbaru students. The sample of this research are 100 respondents who are active students of STIE Pelita Indonesia Pekanbaru and the research method used is multiple linear regression analysis method. The results show that the variable of service quality, satisfaction, incentive partially have significant effect on word of mouth behavior on students. Through this research, the management of STIE Pelita Indonesia need to improve the academic service to the students and to maintain the incentive as one way to promote STIE Pelita Indonesia.
\end{abstract}

Keywords : The quality of service, satisfaction, incentive and word of mouth

\begin{abstract}
ABSTRAK
Peningkatan jumlah perguruan tinggi di Indonesia saat ini menuntut seluruh perguruan tinggi baik negeri maupun swasta untuk dapat meningkatkan kualitas persaingan. Salah satunya adalah melalui strategi marketing yang tepat. Penelitian ini bertujuan untuk mengetahui pengaruh kualitas pelayanan, kepuasan dan insentif terhadap word of mouth mahasiswa STIE Pelita Indonesia Pekanbaru. Sampel penelitian ini sebanyak 100 responden yang merupakan mahasiswa aktif STIE Pelita Indonesia Pekanbaru dan metode penelitian yang digunakan adalah metode analisis regresi linear berganda. Hasil test menunjukkan bahwa variabel kualitas pelayanan, kepuasan, insentif secara parsial berpengaruh signifikan terhadap word of mouth di STIE Pelita Indonesia Pekanbaru. Melalui penelitian ini diharapkan manajemen STIE Pelita Indonesia mampu meningkatkan pelayanan akademik terhadap mahasiswa dan mempertahankan pemberian insentif sebagai salah satu bentuk promosi STIE Pelita Indonesia. Kata Kunci : Kualitas pelayanan, kepuasan, insentif, dan word of mouth
\end{abstract}

\section{PENDAHULUAN}

Dalam era globalisasi, peranan pendidikan dalam kehidupan sangatlah penting bagi menciptakan generasi unggul yang dapat membawa perubahan dan kemajuan dalam suatu negara. Pendidikan menjadi kebutuhan bagi setiap manusia, sehingga manusia berusaha untuk mendapatkan pendidikan yang setinggi-tingginya sebagai bekal untuk bersaing di dunia kerja. Menurut Undang-Undang No. 20 Tahun 2003 tentang sistem Pendidikan Nasional, pendidikan yaitu usaha sadar dan terencana untuk mewujudkan 
suasana belajar dan proses pembelajaran agar peserta didik secara aktif mengembangkan potensi dirinya untuk memiliki kekuatan spiritual keagamaan, pengendalian diri, kepribadian, kecerdasan, akhlak mulia, serta keterampilan yang diperlukan dirinya, masyarakat, bangsa dan negara. Dengan pentingnya peranan pendidikan, maka dalam Undang Undang Dasar 1945 diamanatkan setiap warga negara berhak mendapatkan pendidikan, pengajaran dan pemerintah berusaha untuk menyelenggarakan suatau sistem pendidikan nasional yang pelaksanaannya diatur dalam undangundang.

Pendidikan merupakan faktor utama dalam pembentukan pribadi manusia. Pendidikan sangat berperan dalam membentuk baik atau buruknya pribadi manusia menurut ukuran normatif. Menyadari akan hal tersebut, pemerintah sangat serius untuk menangani masalah pendidikan di Indonesia. Dengan perhatian dari pemerintah diharapkan muncul generasi penerus bangsa yang berkualitas dan mampu menyesuaikan diri untuk hidup bermasyarakat, berbangsa dan bernegara.

Perguruan Tinggi sebagai salah satu instrumen pendidikan nasional diharapkan dapat menjadi pusat penyelenggaraan dan pengembangan pendidikan tinggi serta pemeliharaan, pembinaan dan pengembangan ilmu pengetahuan, eknomi sebagai suatu masyarakat ilmiah yang dapat meningkatkan mutu kehidupan bermasyarakat, berbangsa, dan bernegara. Untuk mencapai tujuan pendidikan nasional seperti yang tercantum dalam Undang - Undang No. 20 tahun 2003 tentang Sistem Pendidikan Nasional, penyelenggara pendidikan nasional dilakukan oleh pemerintah melalui Perguruan Tinggi
Swasta (PTS). Berikut grafik jumlah mahasiswa di PTS Pekanbaru:

\section{Jumlah Mahasiswa}

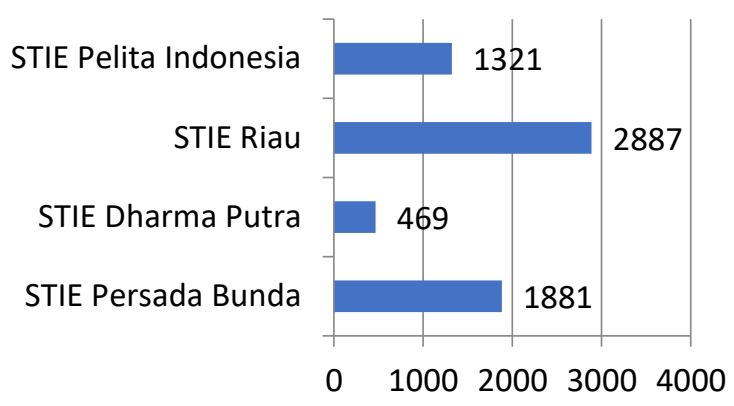

Sumber : https://forlap.ristekdikti.go.id, 2016/2017

\section{Gambar 1. Jumlah Mahasiswa di PTS Pekanbaru}

Pada tahun 2017, jumlah perguruan tinggi yang terdaftar mencapai 60 unit. Kemudian di ambil 4 perguruan tinggi swasta sebagai sampling pembanding bahwa persaingan PTS - PTS di Pekanbaru cukup bersaing , Pada Grafik tersebut untuk angkat yang paling dominan di minati mahasiswa yaitu STIE Riau dengan angka 2.887 mahasiswa sedangkan angkat terendah pada STIE Dharma Putra dengan angka 469 Mahasiswa.

Dengan seiring bertambahnya perguruan tinggi di Pekanbaru khususnya di Perguruan Tinggi Swasta (PTS) menuntut seluruh PTS untuk mengembangkan sumber-sumber keunggulan bersaing guna untuk meningkatkan jumlah funding mahasiswa di setiap tempat, maka dari itu digunakan fungsi media marketing. Fungsi marketing tersebut dilakukan oleh mahasiswa tersebut secara tidak sadar, dengan kata lain mahasiswa secara langsung mempromosikan perguruannya masing - masing jika merasa puas.

Perubahan yang kian cepat di 
tengah arus globalisasi dan industrialisasi menuntut antisipasi para pengelola pendidikan tinggi, khususnya untuk menghasilkan lulusan yang adaptif. Karna jika tidak dilakukan, maka dampak negatif yang akan diterima PTS - PTS yaitu gulung tikar. Faktanya, dari 2.746 perguruan tinggi swasta (PTS), hanya sekitar 20 persen yang siap menyambut tantangan tersebut, selebihnya dinilai belum siap bersaing di era global. Jangankan bersaing di era globalisasi, bersaing di tingkat lokal saja sudah setengah mati (Hendrawan, 2009).

Hal tersebut disadari pula oleh STIE Pelita Indonesia Pekanbaru, sebuah Perguruan Tinggi yang terletak di Provinsi Riau Kota Pekanbaru. Perhatian pada mutu pelayanan jasa pendidikan yang menekankan pada kepuasan siswa muncul dalam rangka menarik para calon siswa, melayani dan mempertahankan mereka. Peningkatan mutu pendidikan tinggi termasuk di dalam mutu pelayanan akademik dan mutu pengajaran merupakan upaya - upaya yang harus dilakukan agar kepuasan mahasiswa sebagai pelanggan lembaga pendidikan dapat diberikan secara optimal.

STIE Pelita Indonesia Pekanbaru berdiri sejak 29 Agustus 1997. Pelita Indonesia Pekanbaru memiliki 4 program studi yaitu S2 Manajemen, S1 Manajemen, S1 Akuntansi dan D3 Akuntansi. Berikut data jumlah mahasiswa baru yang mendaftar di STIE Pelita Indonesia :

\section{Mahasiswa Baru}

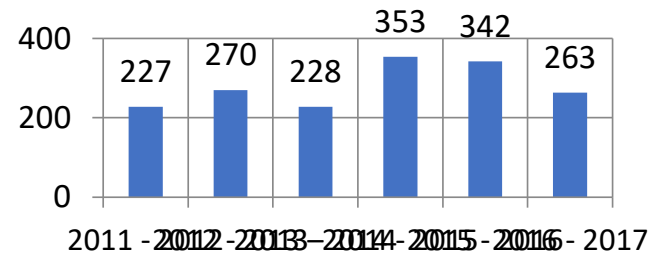

Sumber :Pelita Indonesia Pekanbaru , 2017

\section{Gambar 2. Jumlah Mahasiswa Baru yang Mendaftar}

Berdasarkan data di atas dapat dilihat terjadi fluktuasi setiap tahunnya. Jumlah mahasiswa yang terbanyak didominasi pada tahun 2016 - 2017 dengan angka mencapai 363 mahasiswa, sedangkan jumlah mahasiswa yang paling sedikit jatuh pada tahun 2011 - 2012 yang berjumlah 227 mahasiswa, maka dari itu diperlukan adanya strategi marketing yang baik. Jika dilihat pada grafik tersebut terjadi fluktuasi setiap tahunnya, maka dari itu diperlukan adanya strategi marketing yang baik. Salah satu strategi marketing yang akan digunakan yaitu Word Of Mouth (WOM).

Penelitian Purwati \& Silvia (2017) menunjukkan bahwa masih adanya kesenjangan antara harapan dan kepuasan mahasiswa di Perguruan Tinggi kota Pekanbaru. Hal ini menjadi dasar untuk dilakukannya penelitian lanjutan dimana kesenjangan tersebut akan berdampak pada perilaku Word of Mouth (WOM) Mahasiswa dalam mempromosikan kampusnya.

Penelitian ini dilakukan untuk menganalisis pengaruh kualitas pelayanan, kepuasan, dan insentif terhadap perilaku word of mouth (WOM) mahasiswa STIE Pelita Indonesia.

Promosi dari mulut ke mulut (Word Of Mouth) terjadi jika konsumen membicarakan tentang suatu produk, baik sisi positifnya, maupun sisi negatifnya. Strategi Promosi dari mulut ke mulut merupakan alat yang digunakan oleh perusahaan untuk memasarkan produknya. Selain itu, promosi ini tidak membutuhkan biaya yang besar bahkan bisa gratis jika konsumen puas terhadap produk dan jasa yang 
perusahaan tawarkan.

Menurut (Kotler dan Keller, 2009) word of mouth marketing yaitu kegiatan pemasaran melalui perantara orang ke orang baik secara lisan, tulisan, maupun alat komunikasi elektronik yang berhubungan dengan pengalaman pembelian jasa atau pengalaman menggunakan produk atau jasa.

Menurut

2011) menjelaskan bahwa kualitas pelayanan yaitu sesuatu yang kompleks, dan tamu akan menilai kualitas pelayanan melalui lima indikator pelayanan sebagai ukuranya, yaitu sebagai berikut :

Reliabilitas (Reliability), yaitu kemampuan untuk memberikan secara tepat dan benar jenis pelayanan yang telah dijanjikan kepada tamu.

Responsif (Responsiveness), yai tu kesadaran atau keinginan untuk cepat bertindak membantu tamu dan memberikan pelayanan yang tepat waktu.Kepastian/ jaminan (Assurance), yaitu pengetahuan dan kesopan santunan serta kepercayaan diri para pegawai. Dimensi assurance memiliki ciri-ciri : kompetensi untuk memberikan pelayanan, sopan dan memiliki sifat respek terhadap tamu.

Empati (Empathy), yaitu

memberikan perhatian individu tamu secara khusus. Dimensi empathy ini memiliki ciri-ciri : kemauan untuk melakukan pendekatan, memberikan perlindungan dan usaha untuk mengerti keinginan, kebutuhan dan perasaan tamu.

Nyata (Tangibles), yaitu sesuatu yang nampak atau yang nyata, yaitu : penampilan para pegawai, dan fasilitasfasilitas pisik, lainnya seperti peralatan dan perlengkapan yang menunjang pelaksanaan pelayanan.

Menurut (Kotler, 2007) bahwa Kepuasan Konsumen yaitu perasaan senang atau kecewa seseorang yang muncul setelah membandingkan kinerja (hasil) produk yang dipikirkan terhadap kinerja yang diharapkan.

Dalam penelitian ini indikator kepuasan konsumen menurut (Kotler dan Kevin, 2006) adalah sebagai berikut : Expectation Konsumen akan berharap bahwa bisnis atau perusahaan ini bisa menyediakan fasilitas yang sesuai dengan harapan, Performance Konsumen akan berharap perusahaan bisa memberikan pelayanan yang sesuai dengan harapan, Comparison Setelah mengkonsumsi barang atau jasa maka konsumen akan membandingkan harapan terhadap kinerja barang atau jasa sebelum membeli dengan kinerja aktual barang atau jasa tersebut, Discrepancy Mengindikasikan bagaimana perbedaan antara level kinerja dengan harapan.

Menurut (Winardi, 2001) mendefinisikan insentif yaitu sebagai Dorongan untuk mencapai lebih banyak output kerja untuk mencapai pembayaran lebih banyak terutama dipengaruhi oleh pentingnya relatif banyak uang bagi pihak yang menerimanya dan evaluasi orang yang bersangkutan, tentang adilnya rencana berdasarkan apa yang diperoleh ekstra tersebut. Insentif yaitu tambahan kompensasi di luar gaji atau upah yang diberikan oleh perusahaan. Program insentif terdiri dari insentif individu dan insentif kelompok.

Adapun indikator-indikator yang terdapat dalam insentif menurut (Sarwoto, 2000) yaitu : Bonus diartikan sebagai upah yang diberikan kepada pihak referensi sebagai balas tanda jasa kepada pihak referensi dan Diskon yaitu potongan harga dari suatu barang ataupun jasa yang diberikan kepada konsumen dan ini biasanya termasuk dalam promosi penjualan. 
Variabel Independen

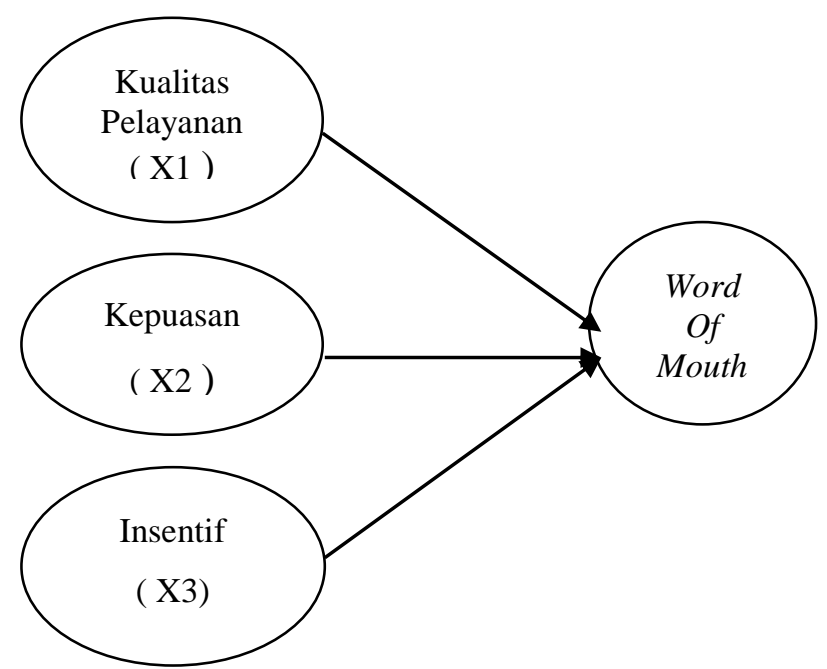

Gambar 3. Kerangka Pemikiran

Berdasarkan kerangka pemikiran di atas maka dirumuskan suatu hubungan antar variable dan hipotesis sebagai berikut :

1. Pengaruh Kualitas Pelayanan (X1) Terhadap Word Of Mouth (Y)

Menurut (Kotler \& G. Armstrong, 2000), kualitas pelayanan merupakan totalitas dari bentuk karakteristik barang dan jasa yang menunjukkan kemampuannya untuk memuaskan kebutuhan pelanggan, baik yang nampak jelas maupun yang tersembunyi.

H1: Terdapat pengaruh yang signifikan antara Kualitas pelayanan terhadap Word Of Mouth

2. Pengaruh Kepuasan (X2) Terhadap Word Of Mouth (Y)

Menurut (Kotler, 2007) bahwa Kepuasan Konsumen yaitu perasaan senang atau kecewa seseorang yang muncul setelah membandingkan kinerja (hasil) produk yang dipikirkan terhadap kinerja yang diharapkan.

H2 : Terdapat Pengaruh yang signifikan antara Kepuasan terhadap Word Of Mouth

3. Pengaruh Insentif (X3) Terhadap Word Of Mouth (Y)
Menurut (Winardi, 2001) mendefinisikan insentif yaitu sebagai Dorongan untuk mencapai lebih banyak output kerja untuk mencapai pembayaran lebih banyak terutama dipengaruhi oleh pentingnya relatif banyak uang bagi pihak yang menerimanya dan evaluasi orang yang bersangkutan, tentang adilnya rencana berdasarkan apa yang diperoleh ekstra tersebut.

H3 : Terdapat Pengaruh yang signifikan antara Insentif terhadap Word Of Mouth

\section{METODE PENELITIAN}

\section{Populasi dan Sampel}

Populasi merupakan subyek penelitian. Menurut (Sugiyono, 2010) populasi yaitu wilayah generalisasi yang terdiri atas obyek/subyek yang mempunyai kualitas dan karakteristik tertentu yang ditetapkan oleh peneliti untuk dipelajari dan kemudian ditarik kesimpulannya.Maka yang menjadi populasi dalam penelitian ini yaitu mahasiswa STIE Pelita Indonesia yang berjumlah sebanyak 1.321 Mahasiswa aktif Tahun Ajaran 2017 - 2018.

Sampel yaitu bagian dari jumlah dan karakteristik yang dimiliki oleh populasi tersebut (Sugiyono, 2011).Dengan demikian sampel yaitu sebagian dari populasi yang karakteristiknya hendak diselidiki, dan bisa mewakili keseluruhan populasinya sehingga jumlahnya lebih sedikit dari populasi. Jadi, 100 orang responden dan responden dipillih secara accidental sampling/kebetulan.

\section{Jenis dan Sumber Data}

Data yang digunakan dalam penelitian ini merupakan data primer yaitu data yang diperoleh langsung dengan membagi angket atau daftar pertanyaan kepada mahasiswa. Data sekunder yang digunakan dalam 
penelitian ini adalah STIE Pelita Indonesia.

\section{Definisi Operasional Variabel Penelitian}

Untuk mempermudah dalam penganalisian maka tiap variabel akan didefinisikan secara operasional yaitu: kualitas pelayanan adalah merupakan nilai terbaik dari pelayanan yang diberikan kepada pelanggan. Oleh sebab itu, kualitas pelayanan dapat diciptakan dengan terlebih dahulu mengidentifikasi ekspektasi tamu tentang pelayanan yang dibutuhkan dan diinginkannya.

Kepuasan Konsumen yaitu perasaan senang atau kecewa seseorang yang muncul setelah membandingkan kinerja (hasil) produk yang dipikirkan terhadap kinerja yang diharapkan.

Insentif merupakan suatu perangsang atau pendorong yang diberikan oleh perusahaan kepada para karyawan agar dalam diri mereka timbul semangat yang lebih besar untuk berprestasi.

Word of mouth marketing yaitu kegiatan pemasaran melalui perantara orang ke orang baik secara lisan, tulisan, maupun alat komunikasi elektronik yang berhubungan dengan pengalaman pembelian jasa atau pengalaman menggunakan produk atau jasa.

\section{Metode Analisis Data}

Analisis ini untuk mengetahui arah hubungan antara variabel independen dengan variabel dependen apakah masing-masing variabel independen berhubungan positif atau negatif dan untuk memprediksi nilai dari variabel dependen apabila nilai variabel independen mengalami kenaikan atau penurunan. Data yang digunakan biasanya berskala interval atau rasio.
Persamaan regresi linear berganda sebagai berikut:

$$
\mathrm{Y}=\mathrm{a}+\beta 1 \mathrm{X} 1+\beta 2 \mathrm{X} 2+\beta 3 \mathrm{X} 3+\mathrm{e}
$$

Keterangan:

$\mathrm{a}=$ Konstanta

$\beta 1=$ Koefisien regresi Kualitas Pelayanan

$\beta 2=$ Koefisien regresi Kepuasan

$\beta 3=$ Koefisien regresi Insentif

$\mathrm{Y}=$ Variabel terikat yaitu Word Of Mouth

$\mathrm{X} 1=$ Variabel bebas yaitu Kepuasan Pelayanan

$\mathrm{X} 2=$ Variabel bebas yaitu Kepuasan

$\mathrm{X} 2=$ Variabel bebas yaitu Insentif

$\mathrm{E}=$ Error (variabel lain tidak dijelaskan)

\section{HASIL DAN PEMBAHASAN Uji Validitas}

Uji validitas digunakan untuk mengukur sah atau tidaknya suatu angket dinyatakan valid jika pernyataan pada angket mampu mengungkapkan sesuatu yang akan diukur oleh angket tersebut. Suatu instrumen dikatakan valid jika instrumen tersebut mengukur apa yang seharusnya diukur. Apabila nilai validitas tiap butir pernyataan > 0,30, maka butir-butir pernyataan tersebut dikatakan valid.

Tabel 1. Uji Validitas Kualitas pelayanan, Kepuasan, Insentif, dan Word Of Mouth

\begin{tabular}{|c|c|c|}
\hline Butir Pertanyaan & r Hitung & Ket \\
\hline Kualitas Pelayanan 1 & 0,683 & Valid \\
\hline Kualitas Pelayanan 2 & 0,671 & Valid \\
\hline Kualitas Pelayanan 3 & 0,589 & Valid \\
\hline Kualitas Pelayanan 4 & 0,667 & Valid \\
\hline Kualitas Pelayanan 5 & 0,676 & Valid \\
\hline Kualitas Pelayanan 6 & 0,737 & Valid \\
\hline Kepuasan 1 & 0,842 & Valid \\
\hline Kepuasan 2 & 0,817 & Valid \\
\hline Kepuasan 3 & 0,787 & Valid \\
\hline Kepuasan 4 & 0,614 & Valid \\
\hline Insentif 1 & 0,748 & Valid \\
\hline Insentif 2 & 0,719 & Valid \\
\hline Insentif 3 & 0,764 & Valid \\
\hline Insentif 4 & 0,796 & Valid \\
\hline Word Of Mouth 1 & 0,805 & Valid \\
\hline
\end{tabular}




\begin{tabular}{ccc}
\hline Word Of Mouth 2 & 0,885 & Valid \\
\hline Word Of Mouth 3 & 0,907 & Valid \\
\hline Word Of Mouth 4 & 0,892 & Valid \\
\hline \multicolumn{2}{l}{ Sumber : Data Olahan SPSS, 2017 }
\end{tabular}

\section{Uji Reliabilitas}

Uji reliabilitas dari masingmasing faktor dengan menggunakan Uji Cronbach's Alpha. Angket dinyatakan reliabel jika mempunyai nilai koefisien alpha yang lebih besar dari 0,6 (Ghozali, 2009). Hasil penelitian diatas dapat dilihat nilai Cronbach's Alpha untuk variabel.

Tabel 2. Uji Reabilitas Kualitas pelayanan, Kepuasan, Insentif, dan Word Of Mouth

\begin{tabular}{ccc}
\hline Butir Pertanyaan & $\begin{array}{c}\text { Cronbach's } \\
\text { Alpha }\end{array}$ & Keterangan \\
\hline $\begin{array}{c}\text { Kualitas } \\
\text { pelayanan }\end{array}$ & 0,753 & Reliabel \\
\hline Kepuasan & 0,765 & Reliabel \\
\hline Insentif & 0,739 & Reliabel \\
\hline Word Of Mouth & 0,891 & Reliabel \\
\hline Sumber :
\end{tabular}

Sumber : Data Olahan SPSS, 2017

Hasil penelitian menunjukkan bahwa kuesioner penelitian untuk masing-masing indikator reliabel. Sehingga penelitian dapat dilanjutkan.

\section{Uji Asumsi Klasik}

\section{Uji Normalitas}

Untuk menguji normalitas data digunakan grafik normal probability plot yang dapat membandingkan nilai observasi dengan nilai yang diharapkan dari suatu distribusi normal. Jika data menyebar disekitar garis diagonal dan mengikuti arah garis diagonal, maka model regresi memenuhi asumsi normalitas. Sebaliknya jika data menjauh dari garis diagonal dan tidak mengikuti arah garis diagonal tersebut, maka model regresi tidak memenuhi asumsi normalitas.

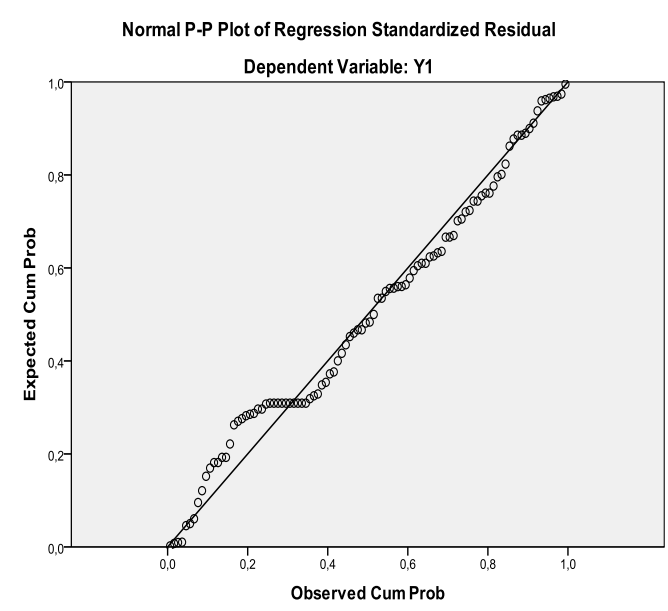

Sumber: Data Olahan SPSS, 2017

\section{Gambar 4. Hasil Pengujian Normalitas}

Berdasarkan gambar diatas dapat dilihat bahwa sebaran data tersebar disekitar garis diagonal probability plot atau mendekati atau tidak terpancar jauh dari garis diagonal. Hal ini berarti data dalam penelitian ini berdistribusi normal.

\section{Uji Multikolinieritas}

untuk menunjukkan multikolinearitas adalah jika toleransi $>0,10$ atau sama dengan nilai VIF $<10$, maka terjadi multikolinearitas.

Tabel 3. Hasil Uji Multikolinearitas

\begin{tabular}{|c|c|c|}
\hline \multirow{2}{*}{ Model } & \multicolumn{2}{|c|}{ Collinearity Statistics } \\
\hline & Tolerance & VIF \\
\hline Kualitas Pelayanan & 0,452 & 2,210 \\
\hline Kepuasan & 0,495 & 2,022 \\
\hline Insentif & 0,826 & 1,210 \\
\hline $\begin{array}{l}\text { Sumber: Data } \\
\text { Dari } \\
\text { bahwa tidak } \\
\text { yang memilil } \\
0,10 \text { yang b } \\
\text { antar varial } \\
\text { perhitungan } \\
\text { Factor (VIF) } \\
\text { hal yang sam } \\
\text { yang memili } \\
\text { kecil dari } 10 \\
\text { bahwa tidak }\end{array}$ & $\begin{array}{l}\text { an SPSS, } 20 \\
\text { el diatas, } \\
\text { a variabel } \\
\text { iilaitolerar } \\
\text { rti tidak } \\
\text { indepen } \\
\text { ai Varian } \\
\text { ang juga n } \\
\text { idak ada } \\
\text { nilai VIF } \\
\text { adi, dapat } \\
\text { multikolir }\end{array}$ & $\begin{array}{l}\text { lilihat } \\
\text { enden } \\
\text { dari } \\
\text { relasi } \\
\text { Hasil } \\
\text { ation } \\
\text { lkkan } \\
\text { riabel } \\
\text { atau } \\
\text { ulkan } \\
\text { antar }\end{array}$ \\
\hline
\end{tabular}


variabel independen dalam model regresi.

\section{Uji Heteroskedastisitas}

Dasar pengambilan keputusan untuk menentukan apakah terjadi heteroskedastisitas atau tidak dalam sebuah model regresiJika titik-titik dalam yang ada membentuk suatu pola tertentu yang teratur (bergelombang, menyempit, kemudian menyempit), maka terjadi heteroskedastisitas. Sedangkan titik-titk tersebut menyebar secara tidak teratur (pola tidak jelas) diatas dan dibawah angka nol pada sumbu Y, maka tidak terjadi heteroskedastisitas.

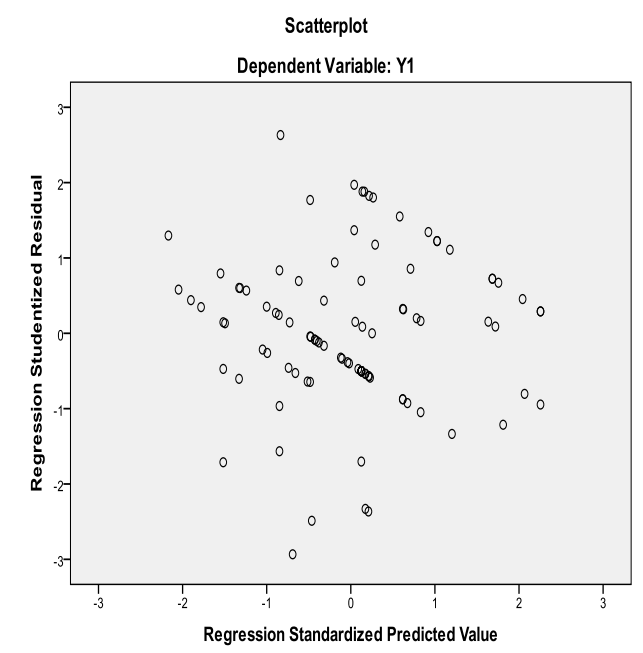

Sumber : Data olahan SPSS, 2017

Gambar 5. Hasil Pengujian Heteroskedastisitas

Berdasarkan grafik diatas dapat

\begin{tabular}{ccc}
\hline \multirow{2}{*}{ Model } & \multicolumn{2}{c}{$\begin{array}{c}\text { Unstandardized } \\
\text { Coefficients }\end{array}$} \\
\cline { 2 - 3 } & B & Std. Error \\
\hline (Constant) & 1,517 & 0,520 \\
\hline X1 & 0,157 & 0,169 \\
\hline X2 & 0,561 & 0,121 \\
\hline X3 & $-0,046$ & 0,101 \\
\hline
\end{tabular}

dilihat titik-titik menyebar secara acak dan tidak membentuk suatu pola tertentu yang jelas tersebar diatas angka nol pada sumbu word of mouth, karena itu dapat disimpulkan bahwa regresi dalam peneltian ini tidak terdapat pengaruh heterokedastisitas.

\section{Uji Autokorelasi}

Uji autokorelasi merupakan kondisi dimana kesalahan pengganggu saling berkorelasi. Uji autokorelasi bertujuan untuk menguji apakah dalam sebuah model regresi linear ada

\begin{tabular}{ccc}
\hline & Nilai & \\
Vuriabel & $\begin{array}{c}\text { Durbin- } \\
\text { Watson }\end{array}$ & Keterangan \\
\hline
\end{tabular}

Kualitas Pelayanan,

Kepuasan, Insentif, dan word of mouth

Tidak Terjadi Autokorelasi

korelasi antara kesalahan pengganggu pada periode $\mathrm{t}$ dengan kesalahan pada periode t-1 (sebelumnya). Jika ada berarti terdapat korelasi.

\section{Tabel 4. Hasil Pengujian} Autokorelasi

Sumber : Data Olahan SPSS, 2017

\section{Uji Autokorelasi dilakukan} dengan menggunakan uji Durbin Watson Test, pada tabel Model Summary diatas diperoleh hasil Durbin Watson Statistic berada pada 1,987. Hal ini berarti bahwa nilai Durbin Watson Statistic terletak antara dU dan $4-\mathrm{dU}=1,736<1,987<2,264$, oleh karena itu diputuskan bahwa model ini sudah terbebas dari kemungkinan adanya autokorelasi.

\section{Analisis Linier Berganda}

Untuk menguji pengaruh variabel independen yaitu variabel produk kualitas pelayanan, kepuasan, insentif terhadap word of mouth mahasiswa pada STIE Pelita Indonesia Pekanbaru, merupakan tujuan analisis regresi berganda.

Tabel 5. Nilai-nilai koefisien pada persamaan regresi linear Berganda Sumber: Data Olahan,2017

Berdasarkan hasil perhitungan SPSS 19.0 diperoleh persamaan regresi linier berganda sebagai berikut :

$Y=1,517+0,157 X 1+0,561 X 2-0,046 X 3$ 
Dimana :

$$
\begin{array}{ll}
\mathrm{Y} & =\text { word of mouth } \\
\mathrm{X} 1 & =\text { kualitas pelayanan } \\
\mathrm{X} 2 & =\text { kepuasan } \\
\mathrm{X} 3 & =\text { insentif }
\end{array}
$$

Dengan persamaan diatas diartikan bahwa : Untuk Konstanta, artinya jika variabel kualitas pelayanan, kepuasan, dan insentif bernilai nol maka word of mouth nya akan bernilai sebesar 1,517. Untuk variabel kualitas pelayanan, artinya adalah bahwa setiap peningkatan satu - satuan kualitas pelayanan maka akan meningkatkan word of mouth sebesar 0,157 , dengan asumsi variabel lain tetap.Untuk variabel kepuasan, artinya adalah bahwa setiap peningkatan kepuasan satu - satuan maka akan meningkatkan word of mouth, sebesar 0,561 dengan asumsi variabel lain tetap.

Untuk variabel insentif, artinya adalah bahwa setiap peningkatan insentif satu - satuan maka akan menurunkan word of mouth sebesar -0,046, dengan asumsi variabel lain tetap.

\section{Uji Model (Uji F)}

Untuk membuktikan hipotesis dalam penelitian ini dengan menggunakan tingkat signifikansi $(\alpha)=5 \%$.

Tabel 6. Hasil Pengujian Uji F

\begin{tabular}{llllll}
\hline Model & $\begin{array}{l}\text { Sum Of } \\
\text { Squares }\end{array}$ & Df & $\begin{array}{l}\text { Mean } \\
\text { Square }\end{array}$ & F & $\begin{array}{c}\text { Sig. sedangkan sisanya sebesar } 65,2 \% \text { di } \\
\text { pengaruhi oleh variabel lain yang tidak }\end{array}$ \\
\hline Regression & 9,879 & 3 & 3,293 & 18,616 & ,000diamati dalam penelitian ini.
\end{tabular}

\begin{tabular}{llllll}
\hline Regression & 9,879 & 3 & 3,293 & 18,616 &, 000 diamati dalam penelitian \\
\hline Residual & 16,982 & 96 &, 177 & & Uji Hipotesis (Uji t)
\end{tabular}

Total 26,860 99 Uji statistik $\mathrm{t}$ merupakan

Sumber : Data Olahan SPSS, 2017

Berdasarkan hasil perhitungan pada tabel diatas diperoleh $\mathrm{F}$ Hitung lebih besar dari F Tabel $(18,616>2,70)$ dan nilai signifikansi $0,000<$ 0.05.Maka hal ini menunjukkan bahwa variabel independen kualitas pelayanan, kepuasan, dan insentif secara simultan atau bersama-sama berpengaruh terhadap word of mouth mahasiswa pada STIE Pelita Indonesia Pekanbaru. Dengan demikian dapat disimpulkan bahwa model penelitian yang digunakan sudah bagus.

\section{Koefisien Determinasi $\left(\mathbf{R}^{2}\right)$}

Koefisien determinasi bertujuan menunjukan besarnya derajat hubungan antara kualitas pelayanan, kepuasan, dan insentif terhadap word of mouth.

Tabel 7. Hasil Pengujian

Koefisien Determinasi

\begin{tabular}{llllll}
\hline Model & $\mathbf{R}$ & $\begin{array}{l}\mathbf{R} \\
\text { Square }\end{array}$ & $\begin{array}{l}\text { Adjusted } \\
\mathbf{R} \\
\text { Square }\end{array}$ & $\begin{array}{l}\text { Std. } \\
\text { Error of } \\
\text { the } \\
\text { Estimate }\end{array}$ & $\begin{array}{l}\text { Durbin- } \\
\text { Watson }\end{array}$ \\
\hline 1 &, $606^{\mathrm{a}}$ &, 368 &, 348 &, 42058 & 1,987 \\
\hline \multicolumn{4}{l}{ Sumber : Data Olahan SPSS, 2017 }
\end{tabular}

Berdasarkan tabel diatas dapat diketahui bahwa Kualitas pelayanan, kepuasan, dan insentif mempunyai hubungan yang kuat dengan variabel terikat, yaitu word of mouth mahasiswa STIE Pelita Indonesia Pekanbaru. Hal ini dapat dibuktikan melalui nilai koefisien Determinasi $\left(\mathrm{R}^{2}\right)$ sebesar 0,348 . Hal ini menunjukkan bahwa semua variabel bebas secara bersamasama memberikan pengaruh terhadap word of mouth mahasiswa STIE Pelita Indonesia Pekanbaru sebesar 34,8\%. Artinya variabel Kualitas pelayanan, kepuasan, dan insentif mempengaruhi word of mouth mahasiswa STIE Pelita Indonesia Pekanbaru sebesar 34,8 \%, analisis pengaruh masing-masing variabel independen terhadap variabel dependen, hal ini digunakan untuk mengetahui bahwa variabel independen Kualitas pelayanan, kepuasan, dan insentif secara parsial mempunyai pengaruh signifikan atau tidak terhadap variabel dependen word of mouth pada tingkat signifikansi $\alpha=5 \%$. 
Tabel 8. Uji Hipotesis (Uji t)

\begin{tabular}{cccc}
\hline Variabel & T Hitung & $\begin{array}{c}\text { T } \\
\text { Tabel }\end{array}$ & Sig \\
\hline $\begin{array}{c}\text { Kualitas } \\
\text { Pelayanan }\end{array}$ & 0,930 & 1.985 & 0,355 \\
\hline Kepuasan & 4,631 & 1.985 & 0,000 \\
\hline Insentif & $-0,452$ & 1.985 & 0,652 \\
\hline $\begin{array}{c}\text { Sumber: Data Olahan SPSS, } 2017 \\
\text { Dari }\end{array}$ & tabel diatas, & hasil \\
$\begin{array}{l}\text { pengujian secara parsial } \\
\text { dijelaskan sebagai berikut : }\end{array}$ & dapat \\
\hline
\end{tabular}

\section{Pengaruh Kualitas Pelayanan}

Terhadap word of mouth

Pengujian ini bertujuan untuk mengetahui apakah variabel Kualitas Pelayanan berpengaruh secara signifikan atau tidak terhadap word of mouth.

$\mathrm{H}_{0}: \mathrm{b} 1=0$, Tidak terdapat pengaruh antara variabel kualitas pelayanan Terhadap word of mouth.

$\mathrm{H}_{1}: \mathrm{b} 1 \neq 0$, Ada pengaruh antara variabel kualitas Pelayanan terhadap word of mouth.

Dari Tabel diatas, diketahui bahwa variabel Kualitas Pelayanan memiliki $\mathrm{t}$ hitung sebesar 0,930 sedangkan $\mathrm{t}$ tabel sebesar 1,985 sehingga $t$ hitung $<\mathrm{t}$ tabel dengan nilai signifikansi untuk variabel kualitas pelayanan sebesar 0,355 yang lebih besar dari taraf signifikansi 0,05. Maka $\mathrm{H}_{0}$ diterima dan $\mathrm{H}_{1}$ ditolak, sehingga dapat disimpulkan bahwa secara parsial variabel Kualitas Pelayanan tidak berpengaruh signifikan terhadap word of mouth.

Pengaruh kepuasan Terhadap word of mouth

Pengujian ini bertujuan untuk mengetahui apakah variabel kepuasan berpengaruh secara signifikan atau tidak terhadap word of mouth.

$\mathrm{H}_{0}: \mathrm{b} 2=0$, Tidak terdapat pengaruh antara variabel kepuasan terhadap word of mouth.
$\mathrm{H}_{1}: \mathrm{b} 2 \neq 0$, Ada pengaruh antara variabel kepuasan terhadap word of mouth.

Dari Tabel diatas, diketahui bahwa variabel kepuasan memiliki $t$ hitung sebesar 4,631 sedangkan t tabel sebesar 1,985 sehingga $\mathrm{t}$ hitung $>\mathrm{t}$ tabel dengan nilai signifikansi untuk variabel harga sebesar 0,000 yang lebih kecil dari taraf signifikansi 0,05. Maka $\mathrm{H}_{1}$ diterima dan $\mathrm{H}_{0}$ ditolak, sehingga dapat disimpulkan bahwa secara parsial variabel kepuasan berpengaruh signifikan terhadap word of mouth.

\section{Pengaruh insentif Terhadap word of} mouth.

Pengujian ini bertujuan untuk mengetahui apakah variabel insentif berpengaruh secara signifikan atau tidak terhadap word of mouth.

$\mathrm{H}_{0}: \mathrm{b} 3=0$, Tidak terdapat pengaruh antara variabel insentif terhadap word of mouth.

$\mathrm{H}_{1}: \mathrm{b} 3 \neq 0$, Ada pengaruh antara variabel insentif terhadap word of mouth.

Dari Tabel diatas, diketahui bahwa variabel insentif memiliki $t$ hitung sebesar $-0,452$ sedangkan $t$ tabel sebesar 1,985 sehingga $t$ hitung $<\mathrm{t}$ tabel dengan nilai signifikansi untuk variabel insentif sebesar 0,652 yang lebih besar dari taraf signifikansi 0,05. Maka $\mathrm{H}_{0}$ diterima dan $\mathrm{H}_{1}$ ditolak, sehingga dapat disimpulkan bahwa secara parsial variabel insentif tidak berpengaruh signifikan terhadap word of mouth

\section{Pengaruh Kualitas Pelayanan Terhadap Word Of Mouth}

Berdasarkan hasil penelitian yang diperoleh hasil bahwa kualitas pelayanan tidak berpengaruh secara signifikan terhadap word of mouth artinya semakin tinggi kualitas pelayanan maka word of mouth tidak mengalami peningkatan. 
Hasil penelitian ini bertolak belakang dengan yang dilakukan oleh (Mira dan Ayu 2010) dari hasil analisis menunjukan bahwa adanya pengaruh antara kualitas pelayanan terhadap word of mouth mahasiswa.

Meskipun kualitas pelayanan tidak berpengaruh terhadap word of mouth akan tetapi sebagai institusi pendidikan, perguruan tinggi harus tetap memperbaiki kualitas pelayanan yang ada diantaranya memperbaiki staf akademik dan dosen STIE PI melayani dengan cepat dan bersedia membantu kapan saja saat dibutuhkan, staf akademik dan dosen memberikan perhatian dan usaha untuk memberikan solusi terhadap permasalahan yang dihadapi mahasiswa, dan ruang pelayanan akademik yang tersedia nyaman dan kondusif.

\section{Pengaruh Kepuasan Terhadap Word Of Mouth}

Berdasarkan hasil penelitian yang diperoleh hasil bahwa kepuasan berpengaruh secara signifikan terhadap word of mouth artinya semakin tinggi kepuasan maka word of mouth akan semakin tinggi dan juga sebaliknya.

Hasil penelitian ini dapat didukung dengan penelitian yang dilakukan oleh (Erida , 2009) dari hasil analisis menunjukan bahwa adanya pengaruh antara kepuasan terhadap word of mouth.

Adapun hasil deskriptif dapat memperjelas beberapa hal dalam kepuasan mahasiswa yang harus ditingkatkan oleh Perguruan Tinggi adalah sebagai berikut kenyataan di STIE Pelita Indonesia sesuai dengan harapan sebelum bergabung di STIE Pelita Indonesia, biaya dan administrasi perkuliahan sesuai dengan kualitas yang diberikan STIE Pelita Indonesia, tetap merasa puas dengan fasilitas dan pelayanan di STIE Pelita Indonesia walaupun tidak sesuai dengan harapan sebelumnya.

\section{Pengaruh Insentif Terhadap word of} mouth

Berdasarkan hasil penelitian yang diperoleh hasil bahwa insentif tidak berpengaruh secara signifikan terhadap word of mouth artinya semakin tinggi insentif maka word of mouth tidak mengalami peningkatan.

Hasil penelitian ini bertolak belakang dengan penelitian yang dilakukan oleh (Setiawan dan Kodir, 2015) dari hasil analisis menunjukan bahwa adanya pengaruh antara tempat terhadap word of mouth.

Meskipun Insentif tidak berpengaruh terhadap word of mouth akan tetapi sebagai institusi pendidikan, perguruan tinggi harus tetap memperbaiki insentif yang ada diantaranya telah dijelaskan melalui analisis deskriptif yaitu memberikan voucher bonus kepada mahasiswa yang mereferensikan kampus kepada orang lain, STIE Pelita indonesia memberikan beasiswa kakak dan adik kepada mahasiswa yang berprestasi, dan STIE Pelita Indonesi memberikan beberapa program potongan lainnya sebagai promosi kepada calon mahasiswa.

\section{PENUTUP}

\section{Kesimpulan}

Pengaruh Kualitas pelayanan terhadap word of mouth, berdasarkan hasil penelitian diperoleh hasil bahwa kualitas pelayanan tidak berpengaruh signifikan terhadap word of mouth. Artinya semakin tinggi kualitas pelayanan maka tidak ada pengaruh terhadap word of mouth. Hal ini tidak sejalan dengan penelitian (Mira, 2010) yang menyatakan bahwa kualitas pelayanan berpengaruh terhadap word of mouth. Pengaruh kepuasan terhadap word of mouth, berdasarkan hasil 
penelitian diperoleh hasil bahwa kepuasan berpengaruh signifikan terhadap word of mouth. Artinya semakin tinggi kepuasan maka semakin tinggi word of mouth dan juga sebaliknya. Hal ini sejalan dengan penelitian (Erida, 2009) yang menyatakan bahwa kepuasan berpengaruh terhadap word of mouth. Pengaruh insentif terhadap word of mouth, berdasarkan hasil penelitian diperoleh hasil bahwa insentif berpengaruh signifikan terhadap word of mouth. Artinya semakin tinggi insentif maka tidak ada pengaruh terhadap word of mouth. Hal ini tidak sejalan dengan penelitian (Setiawan dan Kodir, 2015) yang menyatakan bahwa insentif berpengaruh terhadap word of mouth.

\section{Saran}

Meskipun kualitas pelayanan dan insentif tidak pengaruh terhadap word of mouth akan tetapi sebagai institusi pendidikan, perguruan tinggi harus tetap memperbaiki kualitas pelayanan dan insentif yang ada diantaranya memperbaiki memperbaiki staf akademik dan dosen STIE PI melayani dengan cepat dan bersedia membantu kapan saja saat dibutuhkan, staf akademik dan dosen memberikan perhatian dan usaha untuk memberikan solusi terhadap permasalahan yang dihadapi mahasiswa, dan ruang pelayanan akademik yang tersedia nyaman dan kondusif. Bagi peneliti selanjutnya, penelitian ini dibatasi pada kualitas pelayanan, kepuasan, dan insentif karena itu perlu dilakukan penelitian lanjut mengenai variabel variabel lain yang memperngaruhi word of mouth, misalnya promosi, mengingat adanya faktor lain yang mempengaruhi word of mouth sebesar $65,2 \%$. Jadi, peneliti selanjutnya menggunakan teknik probability sampling mengingat teknik tersebut lebih menghasilkan hasil yang maksimal karena penyebaran angket dilakukan secara random dan tidak terjadi bias atau berdasarkan kepentingan semata.

\section{DAFTAR PUSTAKA}

Erida. (2009). Pengaruh kepuasan konsumen dan insentif terhadap perilaku WOM (Word Of Mouth) konsumen jasa angkutan penumpang bis antar kota antar propinsi kelas eksekutif di Bandung. Jambi.

Ghozali. (2009). Analisis Multivariate Lanjutan Dengan Program SPSS. Semarang: Badan Peneliti Universitas Diponegoro.

Hendrawan. (2009). PTS Indonesia Kian Kedodoran. (online). Retrieved from http:/www.Suarakarya.com

Kotler. (2007). Manajemen Pemasaran (12 jillid). PT.Indeks, Jakarta.

Kotler \& G. Armstrong. (2000). Prinsip-prinsip Pemasaran (edisi ke3). PT. Prenhallindo, Jakarta.

Mira \& Ayu. (2010). Analisis faktor faktor yang mempengaruhi Word Of Mouth mahasiswa Unimus. Semarang.

Kotler Philip \& Kevin Lane Keller. (2006). Marketing Management. Pearson Education Inc.

Kotler Philip dan Kevin Lane Keller. (2009). Manajemen Pemasaran (edisi 13). Jakarta: Erlangga.

Purwati, A.A \& Sitompul, S.S. Aplikasi Model Kano dalam Pengukuran Kualitas Perguruan Tinggi Swasta Kota Pekanbaru Berdasarkan Perspektif Mahasiswa. Jurnal Cano Economos 6(2):93-110.

Sarwoto. (2000). Dasar-dasar Organisasi dan Manajemen. Jakarta: Ghalia Indonesia. 
Setiawan 7 Kodir, (2015). pengaruh kepuasan konsumen dan insentif terhadap perilaku word of mouth (WOM) konsumen warnet di kelurahan Dinoyo kota Malang. Malang. 13(1).

Sugiyono. (2010). Metode Penelitian Pendidikan Pendekatan Kuantitatif, kualitatif, dan $R \& D$. Bandung: Alfabeta.

Sugiyono. (2011). Metode Penelitian Pendidikan Pendekatan Kuantitatif, kualitatif, dan $R \& D$. Bandung: Alfabeta.

Sulastiyono, A. (2011). Manajemen Penyelenggaraan Hotel.Seri manajemen Usaha Jasa Sarana Pariwisata dan Akomodasi. Alfabeta.

Widyasari \& Fifilia. (2009) Analisis Pengaruh Produk, Harga, Promosi, Lokasi terhadap Keputusan Pembelian Rumah ( Studi pada Perumahan Graha Estetika Semarang ). Telaah Manajemen 6(2), 159-169.

Winardi. (2001). Motivasi \& Pemotivasian dalam Manajemen. jakarta: PT. RajaGrafindo Persada. 